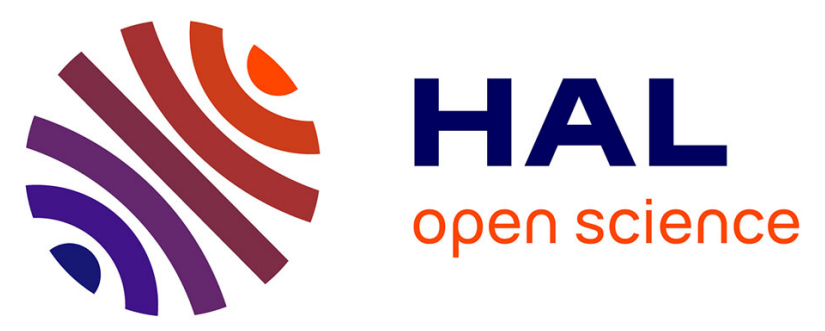

\title{
Photocatalyzed Sulfide Oxygenation with Water as the Unique Oxygen Atom Source
}

Pascal Guillo, Olivier Hamelin, Pinar Batat, Gediminas Jonusauskas, Nathan D. Mcclenaghan, Stéphane Menage

\section{- To cite this version:}

Pascal Guillo, Olivier Hamelin, Pinar Batat, Gediminas Jonusauskas, Nathan D. Mcclenaghan, et al.. Photocatalyzed Sulfide Oxygenation with Water as the Unique Oxygen Atom Source. Inorganic Chemistry, 2012, 51 (4), pp.2222-2230. 10.1021/ic2022159 . hal-00676488

\section{HAL Id: hal-00676488 \\ https://hal.science/hal-00676488}

Submitted on 30 Aug 2018

HAL is a multi-disciplinary open access archive for the deposit and dissemination of scientific research documents, whether they are published or not. The documents may come from teaching and research institutions in France or abroad, or from public or private research centers.
L'archive ouverte pluridisciplinaire HAL, est destinée au dépôt et à la diffusion de documents scientifiques de niveau recherche, publiés ou non, émanant des établissements d'enseignement et de recherche français ou étrangers, des laboratoires publics ou privés.

\section{(1)(1) $\$(0)$}

Distributed under a Creative Commons Attribution - NonCommercial - ShareAlikel 4.0 


\title{
Photocatalyzed Sulfide Oxygenation with Water as the Unique Oxygen Atom Source
}

\author{
Pascal Guillo, ${ }^{\dagger}$ Olivier Hamelin, ${ }^{* \dagger}{ }^{\dagger}$ Pinar Batat, ${ }^{\ddagger}$ Gediminas Jonusauskas, ${ }^{\ddagger}$ Nathan D. McClenaghan, ${ }^{\ddagger}$ \\ and Stéphane Ménage ${ }^{\dagger}$ \\ ${ }^{\dagger}$ Laboratoire de Chimie et Biologie des Métaux, UMR 5249 Université Grenoble I CNRS CEA CEA Grenoble, 17 Avenue des \\ Martyrs, 38054 Grenoble, France \\ ${ }^{\ddagger}$ Institut des Sciences Moléculaires (UMR 5255)/Centre de Physique Moléculaire, Optique et Hertzienne (UMR 5798), \\ CNRS/Université Bordeaux I, 351 crs de la Libération, 33405 Talence, France
}

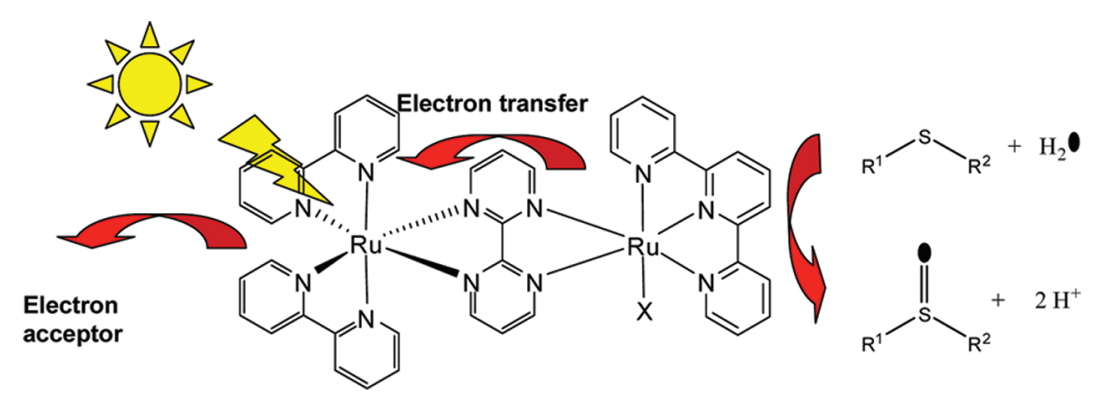

\begin{abstract}
In our research program aiming to develop new ruthenium based polypyridine catalysts for oxidation we were interested in combining a photosensitizer and a catalytic fragment within the same complex to achieve catalytic light driven oxidation. To respond to the lack of such conjugates, we report here a new catalytic system capable of using light to activate water molecules in order to perform selective sulfide oxygenation into sulfoxide via an oxygen atom transfer from $\mathrm{H}_{2} \mathrm{O}$ to the substrate with a TON of up to $197 \pm 6$. On the basis of electrochemical and photophysical studies, a proton coupled electron transfer process yielding to an oxidant $\mathrm{Ru}(\mathrm{IV})$-oxo species was proposed. In particular, the synergistic effect between both partners in the dyad yielding a more efficient catalyst compared to the bimolecular system is highlighted.
\end{abstract}

\section{INTRODUCTION}

In the past decade, a tremendous amount of effort has been devoted to solar energy to chemical energy conversion to promote chemical reactions of interest. ${ }^{1}$ To perform such a transformation, ruthenium polypyridine complexes, thanks to their interesting photophysical properties, have emerged as candidates of choice. ${ }^{2}$ Since the pioneering work of Deronzier et al. about 20 years ago, development of photocatalytic systems for organic synthesis has attracted very little attention until now. ${ }^{3}$ Currently, the necessary search for new energies has stimulated researchers to design new photocatalysts. As a consequence, in the past few years the number of photoredox catalysts has then increased spectacularly in the literature. ${ }^{4}$ Among others, one can cite the very efficient systems reported by T. P. Yoon ${ }^{4 \mathrm{~g}}$ and C. R. J. Stephenson ${ }^{4 \mathrm{f}}$ for $[2+2]$ cycloaddition of enones and reductive halogenation, respec tively. By combining an inorganic catalyst $\left(\left[\mathrm{Ru}(\mathrm{bpy})_{3}\right]^{2+}\right)$ as photoredox catalyst with a chiral amine as an organocatalyst to perform efficient enantioselective alkylation of aldehydes, MacMillan et al. reported probably the most elegant example of photoredox catalysis to date. ${ }^{4 i}$ On the other hand, inspired by photosystem II, some heterogeneous and homogeneous systems were developed to perform one of the most challenging reactions, photooxidation of water into dioxygen. ${ }^{5}$ In most of these cases, a ruthenium polypyridine complex acting as catalyst was associated to ruthenium tris(diimine) complexes as photosensitizers. In such catalytic systems it is proposed that after initiation by light an oxidizing ruthenium oxo species is formed due to an intermolecular electron transfer from the catalyst to the sacrificial electron acceptor via the chromophore. In the field of redox catalysis, such high valent species also oxidize a wide range of organic substrates such as alkanes, alkenes, and sulfides. ${ }^{6}$ In the course of the development of new, eco aware catalytic systems and to achieve efficient catalytic light driven oxygenation of organic substrates, we were interested in the design of a photocatalyst combining a photosensitizer and a catalytic fragment within the same entity in order to promote direct electron transfer between both partners. To the best of our knowledge, only two reports using this approach have been published, both very recently. First, during the course of this work, Rocha and co workers reported the use of a dinuclear ruthenium based complex to perform photocatalytic alcohol oxidation into the corresponding 


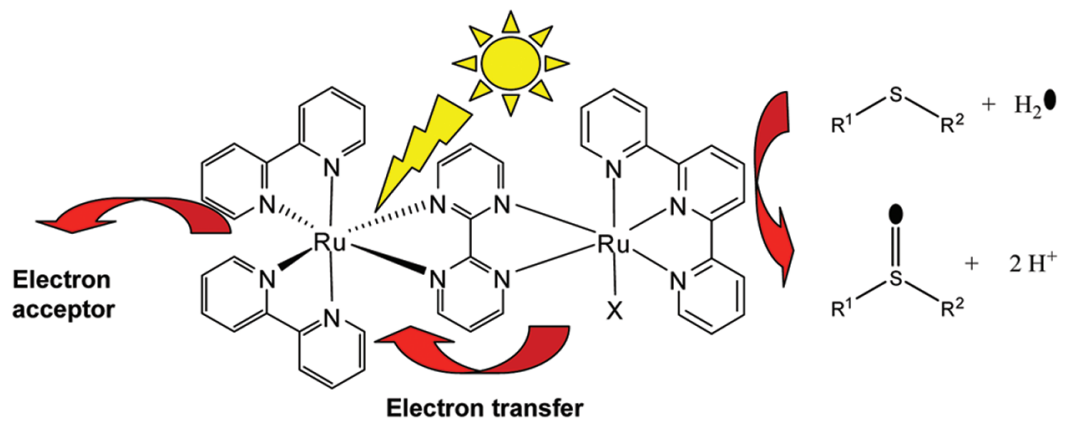

aldehyde or ketone. ${ }^{7}$ However, unlike sulfide and alkane oxygenation, in that case no oxygen atom incorporation into the substrate is required. Very recently we also showed that a similar dyad selectively oxidizes sulfides into sulfoxides. ${ }^{8}$ A proton coupled electron transfer (PCET) process resulting in an oxygen atom transfer from the water molecule to the substrate was involved. On the basis of our previous work using a $\left[(\text { bpy })_{2} \mathrm{Ru}(\right.$ bpym $\left.)\right]$ (bpym $=2,2^{\prime}$ bipyrimidine $)$ fragment as a chiral metalloligand for ketone reduction, ${ }^{9 a}$ we report here a revisited synthesis and full characterization of the dinuclear complex $\left[(\text { bpy })_{2} \mathrm{Ru}(\text { bpym }) \mathrm{Ru}(\text { tpy }) \mathrm{OH}_{2}\right]^{4+}$ (designated $\left.\mathbf{R} \mathbf{u}_{\text {phot }}-\mathbf{R} \mathbf{u}_{\text {cat }}-\mathbf{O H}_{2}\right)$ recently published by T. J. Meyer ${ }^{10}$ while this work was under progress as catalyst for water oxidation using $\mathrm{Ce}(\mathrm{IV})$ as oxidant. In this paper we showed that this catalyst also has the ability to selectively photooxidize sulfide into sulfoxide using water as the unique source of oxygen atom (Scheme 1). In particular, a synergistic effect was observed between both partners of the dyad compared to the bimolecular system. Finally, based on electrochemical and photophysical studies and on literature reports a mechanism involving formation of a $\mathrm{Ru}(\mathrm{IV})=\mathrm{O}$ species thanks to a proton coupled electron transfer process was proposed.

\section{EXPERIMENTAL SECTION}

Materials and Methods. $\mathrm{Ru}(\mathrm{bpy})_{2} \mathrm{Cl}_{2} \cdot 6 \mathrm{H}_{2} \mathrm{O}$ and $\mathrm{RuCl}_{3}$ were purchased from Strem Chemicals. Bipyrimidine, 2,2':6',2" terpyridine, and $\left[\mathrm{Co}\left(\mathrm{NH}_{3}\right)_{5} \mathrm{Cl}\right]\left[\mathrm{Cl}_{2}\right]$ were obtained from Sigma Aldrich. Solvents used in synthetic procedures were analytical grade. All experiments involving ruthenium complexes were carried out in the absence of light to avoid any racemization process.

$\left[(\text { bpy })_{2} \mathrm{Ru}(\right.$ bpym $\left.\left.)\right]\right)\left[\mathrm{PF}_{6}\right]_{2}{ }^{9}$ (named $\left.\mathbf{R u}_{\text {phot }}\right), \mathrm{Ru}($ tpy $) \mathrm{Cl}_{3}{ }^{11}$ $[($ bpym $) \mathrm{Ru}($ tpy $) \mathrm{Cl}]\left[\mathrm{PF}_{6}\right]^{12}$ (named $\left.\mathbf{R u}_{\text {cat }}-\mathrm{Cl}\right)$, and $[($ bpym $) \mathrm{Ru}($ tpy) $\left.\mathrm{OH}_{2}\right]\left[\mathrm{PF}_{6}\right]_{2}{ }^{13}$ (named $\mathbf{R u}$ cat $-\mathbf{O H}_{2}$ ) were prepared according to literature methods. The purity of each complex was confirmed by NMR spectroscopy on the basis of published data.

${ }^{1} \mathrm{H}$ NMR spectra were recorded on a Bruker Avance DPX $300 \mathrm{MHz}$ NMR spectrometer at room temperature.

Elemental analyses were conducted at the Service Central d'Analyze CNRS, Solaize, France using the ICP AES method for metal titration.

Electrospray ionization mass spectrometry measurements were performed on a LXQ linear ion trap (Thermo Scientific, San Jose, CA) equipped with an electrospray source in an aqueous or aqueous/ acetone mixture. Electrospray full scan spectra in the range $\mathrm{m} / \mathrm{z} 50-$ $2000 \mathrm{amu}$ were obtained by infusion through fused silica tubing at $2-$ $10 \mu \mathrm{L} \cdot \mathrm{min}^{-1}$. The LXQ calibration was achieved according to the standard calibration procedure from the manufacturer (mixture of caffeine/MRFA and Ultramark 1621). The temperature of the heated capillary of the LXQ was set to the range $150-200{ }^{\circ} \mathrm{C}$; the ion spray voltage was in the range $1-3 \mathrm{kV}$. The experimental isotopic profile was compared in each case to the theoretical one.
Absorption spectra were recorded with a Varian Cary 1Bio spectrophotometer.

Cyclic voltammetry experiments were performed on a computer controlled Biologic VMP2 potentiostat. Electrochemical measure ments were carried out under nitrogen. A standard three electrode configuration was used consisting of a basal carbon $(3 \mathrm{~mm}$ in diameter) disk as the working electrode, an auxiliary platinum wire, and an $\mathrm{Ag} / \mathrm{AgCl} /$ aqueous $\mathrm{AgCl}_{\text {sat }}+\mathrm{KCl} 3 \mathrm{~mol} \cdot \mathrm{L}^{-1}$ (hereafter named $\mathrm{Ag} / \mathrm{AgCl}$ ) reference electrode closed by a Vicor frit and directly dipped into the solution. The working electrode was polished on a MD Nap polishing pad with a $1 \mu \mathrm{m}$ monocrystalline diamond DP suspension and activated using a reported procedure. ${ }^{14}$ Solution concentrations were $1 \mathrm{mM}$ for the complex and $0.1 \mathrm{M}$ for the $\mathrm{pH} 6.8$ sodium phosphate buffer. RDE experiments were carried out with a EG\&G PAR $273 \mathrm{~A}$ potentiostat at $20 \mathrm{mV} \cdot \mathrm{s}^{-1}$ with a glassy carbon rotating disk electrode ( $3 \mathrm{~mm}$ in diameter; $500 \mathrm{rpm}$ ).

Photooxidation of thioethers was investigated under irradiation with a $180 \mathrm{~W}$ xenon arc lamp equipped with a $390 \mathrm{~nm}$ cutoff filter and a water jacket to remove UV and IR radiation, respectively. During the experiments, samples were placed at $15 \mathrm{~cm}$ from the lamp.

Optical properties: Dilute solutions studied were either air equilibrated or degassed by multicycle freeze-pump-thaw cycles.

The transient absorption/time resolved fluorescence setup was built as follows. A frequency tripled Nd:YAG amplified laser system (30 ps, $30 \mathrm{~mJ}$ at $1064 \mathrm{~nm}, 20 \mathrm{~Hz}$, Ekspla model PL 2143) output was used to pump an optical parametric generator (Ekspla model PG 401) producing tunable excitation pulses in the range $410-2300 \mathrm{~nm}$. The residual of fundamental laser radiation was focused in a high pressure Xe filled breakdown cell where a white light pulse for sample probing was produced. All light signals were analyzed by a spectrograph (Princeton Instruments Acton model SP2300) coupled with a high dynamic range streak camera (Hamamatsu C7700). Accumulated sequences (sample emission, probe without and with excitation) of pulses were recorded and treated by HPDTA (Hamamatsu) software to produce two dimensional maps (wavelength vs delay) of transient absorption intensity in the range $300-800 \mathrm{~nm}$. Typical measurement error was better than $10^{-3}$ O.D.

Transient absorption on the subpicosecond time scale: A Ti:Sapphire laser system emitting pulses of $0.6 \mathrm{~mJ}$ and $30 \mathrm{fs}$ at 800 $\mathrm{nm}$ and $1 \mathrm{kHz}$ pulse repetition rate (Femtopower Compact Pro) with an optical parametric generator (Light Conversion Topas C) and sequential frequency mixers was used to excite samples at the maximum of the steady state absorption band. White light continuum $(360-1000 \mathrm{~nm})$ pulses generated in a $5 \mathrm{~mm} \mathrm{D}_{2} \mathrm{O}$ cell were used as a probe. The variable delay time between excitation and probe pulses was obtained using a delay line with $0.1 \mu \mathrm{m}$ resolution. The solutions were placed in a $1 \mathrm{~mm}$ circulating cell. White light signal and reference spectra were recorded using a two channel fiber spectrometer (Avantes Avaspec 2048 2). A home written acquisition and experi ment control program in LabView made recording transient spectra with an average error less than $10^{-3}$ of optical density for all wavelengths possible. The temporal resolution of our setup was better than 50 fs. A temporal chirp of the probe pulse was corrected by a computer program with respect to a Lawrencian fit of a Kerr signal generated in a $0.2 \mathrm{~mm}$ glass plate used in place of the sample. 
Scheme 2. Synthesis of $\left[\mathrm{Ru}_{\mathrm{phot}}-\mathrm{Ru} \mathrm{cat}-\mathrm{Cl}\right]\left[\mathrm{PF}_{6}\right]_{3}$ and $\left[\mathrm{Ru}_{\mathrm{phot}}-\mathrm{Ru}_{\mathrm{cat}}-\mathrm{OH}_{2}\right]\left[\mathrm{PF}_{6}\right]_{4}{ }^{a}$

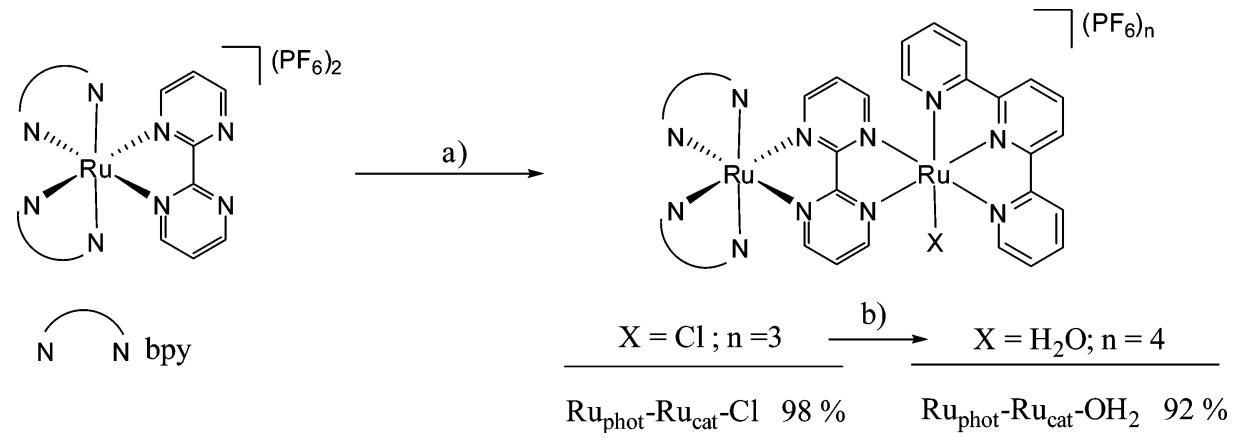

${ }^{a}$ Conditions: (a) $\mathrm{Ru}($ tpy $) \mathrm{Cl}_{3}$, EtOH- $\mathrm{H}_{2} \mathrm{O}$ (2:1), reflux; (b) AgOTf, $\mathrm{H}_{2} \mathrm{O}$ reflux.

Actinomery experiments were performed using potassium ferriox alate as an actinometer according to a reported procedure. ${ }^{15}$ A $150 \mathrm{~W}$ xenon lamp equipped with a monochromator $(\lambda=436 \mathrm{~nm})$ was used. The light intensity of the monochromatic light was determined as 7.3 $\times 10^{-11}$ einstein $\cdot \mathrm{s}^{-1}$. The variation of the absorbance at $510 \mathrm{~nm}$ of the solution as a function of irradiation time is shown in Figure S1, Supporting Information.

The photochemical photooxygenation was performed in a square quartz cuvette ( $10 \mathrm{~mm}$ path length) containing a mixture of catalyst, 4 bromophenyl methyl sulfide substrate, and Co(III) salt in a 0.1:50:100 $\mathrm{mM}$ ratio in $0.1 \mathrm{M}$ phosphate buffer ( $\mathrm{pH}$ 6.8). Formation of the product was monitored by gas chromatography (Perkin Elmer Autosystem XL) taking aliquots from the reaction mixture and using benzophenone as reference. A quantum yield of 0.32 was determined in the conditions described above.

Synthesis and Characterization. [(bpy) $\left.{ }_{2} R u(b p y m) R u(t p y) C l\right]-$ $\left[P F_{6}\right]_{3} \quad\left(\left[R u_{\text {phot }}-R u_{c a t}-C I\right]\left[P F_{6}\right]_{3}\right)$. To a solution of $\left[(\mathrm{bpy})_{2} \mathrm{Ru}\right.$ (bpym) $]\left[\mathrm{PF}_{6}\right]_{2}(300 \mathrm{mg}, 0.35 \mathrm{mmol})$ in $24 \mathrm{~mL}$ of a $2: 1$ ethanol-water mixture, $\mathrm{Ru}(\mathrm{tpy}) \mathrm{Cl}_{3}(230 \mathrm{mg}, 0.52 \mathrm{mmol})$ was added. The resulting solution was refluxed for $3 \mathrm{~h}$. After cooling to room temperature, an excess of $\mathrm{NH}_{4} \mathrm{PF}_{6}$ was then added to precipitate the complex (addition of water was sometimes required to maximize precipitation). After $1 \mathrm{~h}$ at $-20{ }^{\circ} \mathrm{C}$ the resulting solid was filtered and then washed with cold water. After dissolution of the residue in a minimum amount of acetone the complex was precipitated once again by addition of the solution to a large volume of diethyl ether. After filtration, $\left[\mathbf{R u}_{\text {phot }}-\mathbf{R} \mathbf{u}_{\text {cat }}-\mathbf{C l}\right]\left[\mathrm{PF}_{6}\right]_{3}(470 \mathrm{mg}, 98 \%$ yield) was obtained as a green powder.

${ }^{1} \mathrm{H}$ NMR $\left(300 \mathrm{MHz}\right.$, acetone $\left.d_{6}\right) \delta(\mathrm{ppm})=10.38(\mathrm{dd}, 1 \mathrm{H}, 1.5 \mathrm{~Hz}$, $5.7 \mathrm{~Hz}), 8.89(\mathrm{~d}, 1 \mathrm{H}, 3.6 \mathrm{~Hz}), 8.87(\mathrm{~d}, 1 \mathrm{H}, 3.9 \mathrm{~Hz}), 8.79-8.61(\mathrm{~m}$, 9H), 8.34-8.03 (m, 12H), $7.95(\mathrm{dd}, 2 \mathrm{H}, 5.1 \mathrm{~Hz}, 5.1 \mathrm{~Hz}), 7.76$ (dd, $1 \mathrm{H}, 6 \mathrm{~Hz}, 6 \mathrm{~Hz}), 7.66(\mathrm{dd}, 1 \mathrm{H}, 7.2 \mathrm{~Hz}, 7.2 \mathrm{~Hz}), 7.59-7.50(\mathrm{~m}, 3 \mathrm{H})$, $7.43(\mathrm{dd}, 1 \mathrm{H}, 6.9 \mathrm{~Hz}), 7.26(\mathrm{t}, 1 \mathrm{H}, 5.7 \mathrm{~Hz})$. ESI MS $(\mathrm{m} / \mathrm{z})$ (relative intensity) 1232, $\left\{\left[\mathrm{Ru}_{\mathrm{phot}}-\mathrm{Ru}_{\mathrm{cat}}-\mathrm{Cl}\right]\left[\mathrm{PF}_{6}\right]_{2}\right\}^{+}(5) ; 544,\left\{\left[\mathrm{Ru}_{\mathrm{phot}}-\right.\right.$ $\left.\left.\mathrm{Ru}_{\text {cat }}-\mathrm{Cl}\right]\left[\mathrm{PF}_{6}\right]\right\}^{2+}(28) ; 314,\left\{\left[\mathrm{Ru}_{\text {phot }}-\mathrm{Ru}_{\text {cat }}-\mathrm{Cl}\right]\right\}^{3+}(100)$. UV-vis $\left(\mathrm{H}_{2} \mathrm{O}, \lambda_{\max } \mathrm{nm},\left(\varepsilon, \mathrm{M}^{-1} . \mathrm{cm}^{-1}\right)\right): 236$ (49 800), 280 (71 200), $411(21$ 800), 469 (12 400), 622 (7800). Anal. Calcd for $\left[\mathrm{Ru}_{\mathrm{phot}}-\mathrm{Ru}_{\mathrm{cat}}-\right.$ $\mathrm{Cl}]\left[\mathrm{PF}_{6}\right]_{3}\left(\mathrm{C}_{43} \mathrm{H}_{33} \mathrm{ClF}_{18} \mathrm{~N}_{11} \mathrm{P}_{3} \mathrm{Ru}_{2} \cdot 2 \mathrm{H}_{2} \mathrm{O}\right): \mathrm{C}, 36.5 ; \mathrm{H}, 2.64 ; \mathrm{N}, 10.91$; P, 6.58. Found: C, 36.59; H, 2.59; N, 11.02; P, 6.75.

$\left[(\text { bpy })_{2} \mathrm{Ru}(\right.$ bpym $) \mathrm{Ru}($ tpy $\left.)\left(\mathrm{OH}_{2}\right)\right]\left[\mathrm{PF}_{6}\right]_{4} \quad\left(\left[\mathrm{Ru} u_{\text {phot }}-\mathrm{Ru}_{\mathrm{cat}}-\mathrm{OH}_{2}\right]\left[\mathrm{PF}_{6}\right]_{4}\right)$. To a solution of $\left[(\mathrm{bpy})_{2} \mathrm{Ru}(\mathrm{bpym}) \mathrm{Ru}(\mathrm{tpy}) \mathrm{Cl}\right]\left[\mathrm{PF}_{6}\right]_{3} \quad\left(\left[\mathrm{Ru}_{\text {phot }}-\right.\right.$ $\left.\left.\mathbf{R u}_{\text {cat }}-\mathbf{C l}\right]\left[\mathrm{PF}_{6}\right]_{3}\right)(200 \mathrm{mg}, 0.15 \mathrm{mmol})$ in $20 \mathrm{~mL}$ of water silver trifluoromethanesulfonate $(373 \mathrm{mg}, 1.5 \mathrm{mmol})$ was added and the solution was refluxed for $2 \mathrm{~h}$. After cooling to room temperature, an excess of $\mathrm{NH}_{4} \mathrm{PF}_{6}$ was then added to precipitate the complex (addition of water is sometimes required to maximize precipitation). After $1 \mathrm{~h}$ at $0{ }^{\circ} \mathrm{C}$ the solid was filtered and then washed with cold water. The complex was then dissolved in a minimum of acetone and then reprecipitated by addition of the solution to a large volume of diethyl ether. After filtration, $\left[\mathbf{R u}_{\mathrm{phot}}-\mathbf{R u}_{\mathrm{cat}}-\mathbf{O H}_{2}\right]\left[\mathrm{PF}_{6}\right]_{4}(200 \mathrm{mg}, 92 \%$ yield) was obtained as a green powder.
${ }^{1} \mathrm{H}$ NMR $\left(300 \mathrm{MHz}\right.$, acetone $\left.d_{6}\right) \delta(\mathrm{ppm})=10.07(\mathrm{~d}, 1 \mathrm{H}, 5.7 \mathrm{~Hz})$, $8.91-8.87(\mathrm{~m}, 5 \mathrm{H}), 8.79-8.68(\mathrm{~m}, 5 \mathrm{H}), 8.58(\mathrm{~d}, 1 \mathrm{H}, 5.4 \mathrm{~Hz}), 8.48(\mathrm{t}$, $1 \mathrm{H}, 8.1 \mathrm{~Hz}), 8.33-8.16(\mathrm{~m}, 9 \mathrm{H}), 8.08$ (dd, $2 \mathrm{H}, 5.4 \mathrm{~Hz}, 12.6 \mathrm{~Hz}), 7.93$ (d, $2 \mathrm{H}, 5.7 \mathrm{~Hz}), 7.74(\mathrm{dd}, 1 \mathrm{H}, 6.3 \mathrm{~Hz}, 6.3 \mathrm{~Hz}), 7.69-7.61(\mathrm{~m}, 2 \mathrm{H})$, 7.58-7.50 (m, 3H), $7.28(\mathrm{t}, 1 \mathrm{H}, 5.7 \mathrm{~Hz}), 6.27(\mathrm{~s}$ large, $2 \mathrm{H})$. ESI MS $(m / z)$ (relative intensity) 1216, \{[ $\left.\left[\mathrm{Ru}_{\text {phot }}-\mathrm{Ru}_{\text {cat }}-\mathrm{OH}_{2}\right]\left[\mathrm{PF}_{6}\right]_{2}-\mathrm{H}^{+}\right\}^{+}$ (7); 534.5, $\left\{\left[\mathrm{Ru}_{\text {phot }}-\mathrm{Ru}_{\mathrm{cat}}-\mathrm{OH}_{2}\right]\left[\mathrm{PF}_{6}\right]-\mathrm{H}^{+}\right\}^{2+}(100)$. UV-vis $\left(\mathrm{H}_{2} \mathrm{O}, \lambda_{\max } \mathrm{nm},\left(\varepsilon, \mathrm{M}^{-1} \cdot \mathrm{cm}^{-1}\right)\right): 278(65900), 303$ (29 900), 331 (12 800), 409 (20 500), 445 (12500), 610 (6900). Anal. Calcd for $\left[\mathrm{Ru}_{\text {phot }}-\mathrm{Ru}_{\text {cat }}-\mathrm{OH}_{2}\right]\left[\mathrm{PF}_{6}\right]_{4} \cdot 2 \mathrm{H}_{2} \mathrm{O}\left(\mathrm{C}_{43} \mathrm{H}_{39} \mathrm{~F}_{24} \mathrm{~N}_{11} \mathrm{O}_{3} \mathrm{P}_{4} \mathrm{Ru}_{2}\right): \mathrm{C}, 33.54$; H, 2.55; N, 10.01. Found: C, 33.42; H, 2.59; N, 9.82.

Standard Conditions for Photocatalytic Sulfide Oxidation. A 0.02 $\mathrm{mM}$ solution of $\left[\mathrm{Ru}_{\mathrm{phot}}-\mathrm{Ru}_{\mathrm{cat}}-\mathrm{OH}_{2}\right]\left[\mathrm{PF}_{6}\right]_{4}$ in a $0.1 \mathrm{M}$ sodium phosphate buffer at $\mathrm{pH} 6.8$ was prepared and stored at $-20{ }^{\circ} \mathrm{C}$.

To $5 \mathrm{~mL}$ of this solution in a Schlenk system 1000 equiv of $\left[\mathrm{Co}\left(\mathrm{NH}_{3}\right)_{5} \mathrm{Cl}\right] \mathrm{Cl}_{2}(25 \mathrm{mg}, 100 \mu \mathrm{mol})$ was added. The solution was degassed for $15 \mathrm{~min}$ by Ar bubbling, and then 500 equiv $(50 \mu \mathrm{mol})$ of substrate was added under an inert atmosphere. The sample was irradiated at $180 \mathrm{~W}$ for $24 \mathrm{~h}$. After extraction of the organic products by dichloromethane $(\times 2)$ and diethyl ether $(\times 2)$ a known quantity of $3,4,5$ trimethoxybenzaldehyde was added as reference. After evapo ration, products were characterized and quantified using ${ }^{1} \mathrm{H}$ NMR spectroscopy by comparison of the integral ratio of the methyl signals of the product and those of the methoxy signals of the reference.

Synthesis and Characterization of the Catalyst. In 2009 the synthesis of the $\mathbf{R} \mathbf{u}_{\text {phot }}-\mathbf{R} \mathbf{u}_{\text {cat }}-\mathbf{O H}_{2}$ complex was achieved in two steps in moderate overall yield (55\%) by condensation of $\mathrm{Ru}(\mathrm{bpy})_{2} \mathrm{Cl}_{2}$ and $[(\text { bpym }) \mathrm{Ru}(\text { tpy })]^{2+}$ to yield the $\mathbf{R u}_{\text {phot }}-\mathbf{R u}_{\text {cat }}-\mathbf{C l}$ precursor. ${ }^{10}$ Subsequent $\mathrm{Cl}^{-} / \mathrm{H}_{2} \mathrm{O}$ exchange was achieved via formation of the $\left[\left(\text { bpy }{ }_{2} \mathrm{Ru}(\text { bpym }) \mathrm{Ru}(\text { tpy })(\mathrm{OTf})\right]^{3+}\right.$ complex $(\mathrm{OTf}=$ trifluorometha nesulfonate $)$ as an intermediate. However, reaction of $\left[(\mathrm{bpy})_{2} \mathrm{Ru}\right.$ (bpym) $]\left[\mathrm{PF}_{6}\right]_{2}{ }^{9}$ (named $\mathrm{Ru}_{\text {phot }}$ ) and $\mathrm{Ru}\left(\right.$ tpy) $\mathrm{Cl}_{3}{ }^{11}$ in a refluxing mixture of 2:1 ethanol-water and subsequent direct substitution of the chloro ligand by a water molecule using $\mathrm{Ag}(\mathrm{OTf})$ in refluxing water (Scheme 2) proved to be more efficient affording the desired $\mathrm{Ru}_{\text {phot }}-$ $\mathbf{R u}_{\text {cat }}-\mathbf{O H}_{2}$ dinuclear complex in higher yield ( $90 \%$ for two steps). The presence of the water molecule as ligand in the final product was confirmed by ${ }^{1} \mathrm{H}$ NMR in acetone $d_{6}$ as a broad singlet at $6.27 \mathrm{ppm}$ and integrated for two protons. This signal disappeared immediately after addition of a few drops of $\mathrm{D}_{2} \mathrm{O}$ as a result of $\mathrm{H}_{2} \mathrm{O} / \mathrm{D}_{2} \mathrm{O}$ exchange (Figure S1, Supporting Information).

Both dinuclear systems were fully characterized by ${ }^{1} \mathrm{H}$ NMR spectroscopy, ESI mass spectrometry, and elemental analyses. ESI mass spectra displayed fragments at 1232 and $1216 \mathrm{~m} / z$ corresponding to the monocations $\left\{\left[\mathbf{R u}_{\text {phot }}-\mathbf{R} \mathbf{u}_{\text {cat }}-\mathbf{C l}\right]\left[\mathrm{PF}_{6}\right]_{2}\right\}^{+}$and $\left\{\left[\mathbf{R u}_{\text {phot }}-\right.\right.$ $\left.\left.\mathbf{R u}_{\text {cat }}-\mathbf{O H}_{2}\right]\left[\mathrm{PF}_{6}\right]_{2}-\mathrm{H}^{+}\right\}^{+}$, respectively. The electronic properties of both complexes were investigated and compared to those of the $\mathbf{R} \mathbf{u}_{\text {phot }}$ system (Table 1, Figure S1, Supporting Information) whose transitions were assigned on the basis of literature reports. ${ }^{9 b, 12,13}$ Assignments of the bands at higher energy $(280-300 \mathrm{~nm})$ were ascribed to ligand centered transitions $\left({ }^{1} \mathrm{LC}\right)$ with $\pi-\pi^{*}$ transitions. Two metal to ligand charge transfer ( $\left.{ }^{1} \mathrm{MLCT}\right)$ bands were also observed at lower energy in the visible region of the electronic 
Table 1. Spectroscopic Data for $\left[(\text { bpy })_{2} \mathrm{Ru}(\right.$ bpym $\left.)\right]\left[\mathrm{PF}_{6}\right]_{2}$ $\left(\left[\mathrm{Ru}_{\text {phot }}\right]\left[\mathrm{PF}_{6}\right]_{2}\right),\left[(\mathbf{b p y})_{2} \mathbf{R u}(\right.$ bpym $) \mathbf{R u}($ tpy $\left.) \mathbf{C l}\right]\left[\mathbf{P F}_{6}\right]_{3}$ $\left(\left[\mathrm{Ru}_{\text {phot }}-\mathrm{Ru}_{\mathrm{cat}}-\mathrm{Cl}\right]\left[\mathrm{PF}_{6}\right]_{3}\right)$, and $\left[(\text { bpy })_{2} \mathrm{Ru}(\right.$ bpym $) \mathrm{Ru}($ tpy $\left.) \mathrm{OH}_{2}\right]\left[\mathrm{PF}_{6}\right]_{4}\left(\left[\mathrm{Ru}_{\text {phot }}-\mathrm{Ru}_{\text {cat }}{ }^{-}\right.\right.$ $\left.\left.\mathrm{OH}_{2}\right]\left[\mathrm{PF}_{6}\right]_{4}\right)^{a}$

\begin{tabular}{|c|c|c|c|}
\hline \multirow[b]{2}{*}{ compound } & \multicolumn{3}{|c|}{$\lambda_{\max } / \mathrm{nm}\left(\varepsilon / \mathrm{M}^{-1} \mathrm{~cm}^{-1}\right)$} \\
\hline & $\pi \rightarrow \pi^{*}$ & \multicolumn{2}{|c|}{$\mathrm{d} \pi_{\text {Ruphot, Rucat }} \rightarrow \pi^{*}$} \\
\hline \multirow[t]{2}{*}[\mathrm{Ru}_{\text{phot}}]{$\left[\mathrm{PF}_{6}\right]_{2}$} & $283(53000)$ & $417(12300)$ & \\
\hline & & $475(6000)$ & \\
\hline \multirow[t]{2}{*}{ 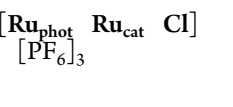 } & $280(71200)$ & $411(21800)$ & $622(7800)^{b}$ \\
\hline & & $469(12400)$ & \\
\hline \multirow[t]{3}{*}[\begin{array}{l}{\mathbf{Ru}_{\text{phot}}}\\
{[\mathrm{PF}_{6}]_{4}}\end{array}\mathbf{Ru}_{\text{cat}}\quad\mathbf{OH}_{2}]{} & $278(65900)$ & $409(20500)$ & $610(6900)^{b}$ \\
\hline & $303(29900)$ & $445(12500)$ & \\
\hline & $331(12800$ & & \\
\hline
\end{tabular}

absorption spectrum at 417 and $475 \mathrm{~nm}$. Addition of the $\mathrm{Ru}_{\text {cat }}$ moiety to the $\mathrm{Ru}_{\text {phot }}$ metalloligand resulted in the appearance of an additional transition at 622 and $610 \mathrm{~nm}$ for $\mathbf{R} \mathbf{u}_{\text {phot }}-\mathbf{R u}_{\text {cat }}-\mathbf{C l}$ and $\mathbf{R} \mathbf{u}_{\text {phot }}-\mathbf{R u}_{\text {cat }}-$ $\mathrm{OH}_{2}$, respectively, attributed to the $\mathrm{d}\left(\mathrm{Ru}_{\text {cat }}\right) \rightarrow \pi^{*}($ bpym $)$ MLCT transition. ${ }^{10}$ Substitution of $\mathrm{Cl}^{-}$for $\mathrm{H}_{2} \mathrm{O}$ results in a significant blue shift of the MLCT of lower energy as a consequence of the destabilization of the $\mathrm{d} \pi_{\text {Rucat }}$ level through $\pi$ donation from $\mathrm{Cl}^{-}$(from 469 to $445 \mathrm{~nm}$ and from 622 to $610 \mathrm{~nm}$ ) in the $\mathbf{R} \mathbf{u}_{\text {phot }}-\mathbf{R u}_{\text {cat }}-\mathbf{C l}$ complex. ${ }^{16}$

Photocatalytic Oxygenation. While various oxidants are used to oxidize sulfides into sulfoxides ${ }^{17}$ very few photocatalytic systems were reported to date to perform such a transformation. ${ }^{8,18}$ Thus, photooxidation of 4 bromophenyl methyl sulfide to the corresponding sulfoxide by $\mathbf{R u}_{\text {phot }}-\mathbf{R u}_{\text {cat }}-\mathbf{O H}_{2}$ using $\left[\mathrm{Co}\left(\mathrm{NH}_{3}\right) \mathrm{Cl}\right] \mathrm{Cl}_{2}$ as an electron acceptor was investigated as the probe reaction with a complex:substrate:Co(III) 1:500:1000 ratio in deoxygenated water (0.1 M phosphate buffer; $\mathrm{pH} 6.8$ ). All photocatalytic experiments were carried out at least three times and under an inert atmosphere in order to prevent photochemical formation of ${ }^{1} \mathrm{O}_{2}$ as potential oxidant. The resulting solution was irradiated with a Xenon lamp $(180 \mathrm{~W})$ equipped with a UV filter $\left(\lambda_{\text {exc }}>390 \mathrm{~nm}\right)$. The resulting products were then extracted from the reaction mixture, characterized, and quantified by ${ }^{1} \mathrm{H}$ NMR spectroscopy. The results are summarized in Table 2. Figure S1, Supporting Information, shows the plot of the turnover number as a function of time for photocatalytic oxidation using the complex $\mathbf{R} \mathbf{u}_{\text {phot }}-\mathbf{R} \mathbf{u}_{\text {cat }}-\mathbf{O H}_{2}$. Up to $131 \pm 6 \mathrm{TON}$ was achieved after $24 \mathrm{~h}$ of light irradiation (entry 2) with an excellent selectivity since no evidence for formation of sulfone could be obtained. Control experiments showed that in the absence of light (entry 3), catalyst, or electron acceptor no product was formed. Similarly to the photosensitizer fragment $\left[(\mathrm{bpy})_{2} \mathrm{Ru}(\mathrm{bpym})\right]^{2+}\left(\mathbf{R u}_{\mathrm{phot}}\right),{ }^{9}$ which alone was not able to oxidize the substrate (entry 4 ), the cation $\left[(\text { bpym }) \mathrm{Ru}(\text { tpy }) \mathrm{OH}_{2}\right]^{2+}\left(\mathbf{R u}_{\text {cat }}-\mathbf{O H}_{2}\right)^{13}$ showed poor activity under light exposition with only $10 \pm 2$ TON (entries 5 and 6). Interestingly, a stoichiometric bimolecular combination of both partners resulted in the formation of the sulfoxide but with a lower efficiency than in the dyad (entry 7). Moreover, both complexes $\left(\mathbf{R u}_{\text {phot }}-\mathbf{R} \mathbf{u}_{\text {cat }}-\mathbf{C l}\right.$ and $\left.\mathbf{R u}_{\text {phot }}-\mathbf{R u}_{\text {cat }}-\mathbf{O H}_{2}\right)$ showed almost similar activity with a TON of about 135 (entries 1 and 2). This may be attributed to conversion of the $\mathbf{R u}_{\text {phot }}-\mathbf{R} \mathbf{u}_{\text {cat }}-\mathbf{C l}$ precatalyst to the $\mathbf{R} \mathbf{u}_{\text {phot }}-\mathbf{R u}_{\text {cat }}-\mathbf{O H}_{2}$ catalyst by a fast $\mathrm{Cl}^{-} / \mathrm{H}_{2} \mathrm{O}$ ligand exchange which could occur in the catalytic conditions. Finally, the quantum yield of the photochemical photooxygenation was determined by actinometry using potassium ferrioxalate as actinometer under irradiation with a monochromatic light $\left(\lambda=436 \mathrm{~nm}\right.$; light intensity $7.3 \times 10^{-11}$ einstein $\left.\cdot \mathrm{s}^{-1}\right) .{ }^{15}$ For the catalytic system:substrate:Co(III) salt, $0.1: 50: 100 \mathrm{mM}$ in $0.1 \mathrm{M}$ phosphate buffer ( $\mathrm{pH}$ 6.8), a quantum yield of 0.32 of the photocatalytic oxygenation was determined.
Table 2. Photocatalytic Oxidation of 4 Bromophenyl Methyl Sulfide $^{a}$

Entry Complex Light TON

\begin{tabular}{|c|c|c|c|}
\hline 1 & $\mathrm{Ru}_{\mathrm{phot}}-\mathrm{Ru}_{\mathrm{cat}}-\mathrm{Cl}$ & 萧 & $140 \pm 10$ \\
\hline 2 & $\mathrm{Ru}_{\mathrm{phot}}-\mathrm{Ru}_{\mathrm{cat}}-\mathrm{OH}_{2}$ & 戠 & $131 \pm 6$ \\
\hline 3 & $\mathrm{Ru}_{\mathrm{phot}}-\mathrm{Ru}_{\mathrm{cat}}-\mathrm{OH}_{2}$ & C & 0 \\
\hline 4 & $\mathrm{Ru}_{\mathrm{phot}}$ & * & $<5$ \\
\hline 5 & $\mathrm{Ru}_{\mathrm{cat}}-\mathrm{OH}_{2}$ & 格 & $<10 \pm 2$ \\
\hline 6 & $\mathrm{Ru}_{\mathrm{cat}}-\mathrm{OH}_{2}$ & C & 0 \\
\hline 7 & $\mathrm{Ru}_{\mathrm{phot}}+\mathrm{Ru}_{\mathrm{cat}}-\mathrm{OH}_{2}^{[\mathrm{b}]}$ & 椋 & $56 \pm 4$ \\
\hline 8 & $\mathrm{Ru}_{\mathrm{phot}}-\mathrm{Ru}_{\mathrm{cat}}-\mathrm{OH}_{2}$ & 嚓 & $195 \pm 8^{[c]}$ \\
\hline \multicolumn{4}{|c|}{$\begin{array}{l}{ }^{a} \text { Complex:Substrate: } \mathrm{Co}(\mathrm{III}) \quad 0.02: 10: 20 \mathrm{mM} \text { in } 0.1 \mathrm{M} \text { phosphate } \\
\text { buffer ( } \mathrm{pH} 6.8) \text { for } 24 \mathrm{~h} \text {. Sun: Xenon lamp }(180 \mathrm{~W}) \text {. Moon: in the } \\
\text { absence of light. }{ }^{b}\left[\mathrm{Ru}_{\text {phot }}\right]=\left[\mathrm{Ru}_{\text {cat }}-\mathrm{OH}_{2}\right]=0.02 \mathrm{mM} \text {. }{ }^{c} \text { After addition } \\
\text { of a second portion of } \mathrm{Co}(\mathrm{III}) \text { salt }(1000 \text { equiv) and additional } 24 \mathrm{~h} \text { of } \\
\text { irradiation. }\end{array}$} \\
\hline
\end{tabular}

Table 3. Photocatalytic Oxidation of a Variety of Sulfides Using $\mathrm{Ru}_{\mathrm{phot}}-\mathrm{Ru}_{\mathrm{cat}}-\mathrm{OH}_{2}$ as Catalyst ${ }^{a}$

\begin{tabular}{|c|c|c|}
\hline \multicolumn{2}{|c|}{ substrate $\mathrm{R}^{1}$} & \multirow{2}{*}{$\frac{\text { TON }}{124 \pm 4}$} \\
\hline $\mathrm{R}^{1} \mathrm{~S} \quad \mathrm{CH}_{3}$ & $\mathrm{R}^{1}=$ phenyl & \\
\hline & $\mathrm{R}^{1}=4$-bromophenyl & $131 \pm 6$ \\
\hline & $\mathrm{R}^{1}=2$-bromophenyl & $133 \pm 4$ \\
\hline & $\mathrm{R}^{1}=4$-methoxyphenyl & $197 \pm 6$ \\
\hline & $\mathrm{R}^{1}=$ 4-nitrophenyl & $51 \pm 5$ \\
\hline alcohol & 1-phenylethanol & $25 \pm 3$ \\
\hline \multirow[t]{3}{*}{ alkene } & trans- $\beta$-methyl styrene & 3 \\
\hline & methyl trans cinnamate & 0 \\
\hline & cis-cyclooctene & 0 \\
\hline
\end{tabular}

${ }^{a}$ Catalyst:Substrate:Co(III) 0.02:10:20 mM in 0.1 M phosphate buffer ( $\mathrm{pH}$ 6.8); Xenon lamp (180 W) for $24 \mathrm{~h}$.

The photocatalytic activity of the catalyst $\mathbf{R} \mathbf{u}_{\text {phot }}-\mathbf{R} \mathbf{u}_{\text {cat }}-\mathbf{O H}_{2}$ was then assayed during oxidation of a variety of sulfides (Table 3 ). With the exception of the 4 nitrophenyl methyl sulfide, all substrates were efficiently converted into their corresponding sulfoxide with TON ranging from $124 \pm 4$ to $197 \pm 6$ and with excellent selectivities since no overoxidation products could be detected. Even though the solubility properties of the various substrates are different in aqueous conditions, it seems that the reactivity is directly correlated to the electronic effect of the para substituent on the substrate. Only $51 \pm 5$ TON was achieved after $24 \mathrm{~h}$ of irradiation with the $\mathrm{NO}_{2}$ electron withdrawing substituent, whereas more than $197 \pm 6$ TON was obtained when the para substituent is the methoxy electron donating group. In the same conditions, lower catalytic activity was observed during alkenes and alcohol oxidation. As an example, only $25 \pm 3$ and 3 TON were achieved during oxidation of 1 phenylethanol and trans $\beta$ methyl styrene into the corresponding ketone and trans epoxide, respectively. No oxidized product could be detected with electron poor alkenes such as cis cyclooctene and methyl trans cinnamate.

The stability of the catalyst toward light was confirmed, first, by irradiation of a solution of the catalyst in phosphate buffer. On the basis of electronic absorption, after $24 \mathrm{~h}$ of light exposure more than 
$70 \%$ of the catalyst remains unchanged (Figure S1, Supporting Information). Second, when a second portion of 1000 equiv of $\mathrm{Co}(\mathrm{III})$ salt was added to the catalytic mixture after $24 \mathrm{~h}$ of irradiation and the resulting solution was irradiated for additional $24 \mathrm{~h}$, the catalytic activity increased about $50 \%$ from $131 \pm 6$ to $195 \pm 8$ TON (Table 2, entry 8 ).

Electrochemical Studies. The electrochemical behavior of both $\mathbf{R} \mathbf{u}_{\text {phot }}-\mathbf{R} \mathbf{u}_{\text {cat }}-\mathbf{O H}_{2}$ and $\mathbf{R} \mathbf{u}_{\text {phot }}-\mathbf{R} \mathbf{u}_{\text {cat }}-\mathbf{C l}$ complexes was investigated

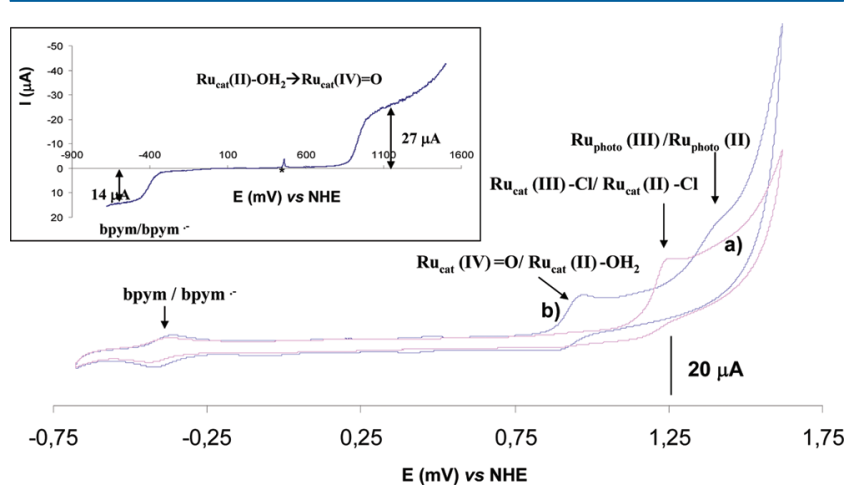

Figure 1. Cyclic voltammograms of the $\mathbf{R u}_{\text {phot }}-\mathbf{R} \mathbf{u}_{\text {cat }}-\mathbf{C l}$ (a) and $\mathbf{R} \mathbf{u}_{\text {phot }}-\mathbf{R} \mathbf{u}_{\text {cat }}-\mathbf{O H}_{2}$ (b) complexes ([concentration] $=1 \mathrm{mM}$ ) in 0.1 $\mathrm{M}$ sodium phosphate buffer at $\mathrm{pH} 6.8 ; 20 \mathrm{mV} \cdot \mathrm{s}^{-1}$. (Inset) $\mathrm{RDE}$ experiment (500 rpm); voltammogram of the $\mathbf{R} \mathbf{u}_{\text {phot }}-\mathbf{R u}_{\text {cat }}-\mathbf{O H}_{2}$ complex $([$ concentration $]=0.5 \mathrm{mM})$ in $0.1 \mathrm{M}$ sodium phosphate buffer at $\mathrm{pH} 6.8$.

Table 4. Electrochemical Data for All Complexes (in V vs NHE) ${ }^{a}$

\begin{tabular}{lccc} 
& \multicolumn{3}{c}{$E_{1 / 2}$} \\
\cline { 2 - 4 } \multicolumn{1}{c}{ compound } & $\begin{array}{c}\text { bpym/ } \\
\text { bpym }\end{array}$ & $\begin{array}{c}\mathrm{Ru}_{\text {cat }}(\text { ox }) / \\
\mathrm{Ru}_{\text {cat }}(\text { (red })\end{array}$ & $\begin{array}{c}\mathrm{Ru}_{\text {phot }}(\mathrm{III}) / \\
\mathrm{Ru}_{\text {phot }}(\mathrm{II})\end{array}$ \\
$\mathbf{R u}_{\text {cat }} \mathbf{C l}$ & 0.70 & +1.00 & \\
$\mathbf{R u}_{\text {cat }} \mathbf{O H}_{2}$ & 0.70 & +0.86 & \\
$\mathbf{R u}_{\text {phot }}$ & 0.66 & & $+1.51^{b}$ \\
$\mathbf{R u}_{\text {phot }} \mathbf{R u}_{\text {cat }} \mathbf{C l}$ & 0.42 & $+1.29^{b}$ & \\
$\mathbf{R u}_{\text {phot }} \mathbf{R u}_{\text {cat }}$ & 0.41 & $+0.92^{b}$ & $+1.46^{b}$ \\
$\mathbf{O H}_{2}$ & & &
\end{tabular}

${ }^{a}[$ complex $]=1 \mathrm{mM}$ in a $0.1 \mathrm{M}$ phosphate buffer ( $\mathrm{pH}$ 6.8). ${ }^{b}$ Irreversible wave; anodic peak.

in a $0.1 \mathrm{M}$ phosphate buffer ( $\mathrm{pH}$ 6.8; Figure 1). Data are reported in Table 4 and compared to those of $\left[(\text { bpy })_{2} \mathrm{Ru}(\text { bpym })\right]^{2+}$ and $\left[\mathrm{Ru}(\text { tpy })(\text { bpym })\left(\mathrm{OH}_{2} \text { or } \mathrm{Cl}\right)\right]^{2+/+}$ model cations for the $\mathbf{R u}_{\text {phot }}$ and $\mathbf{R u}_{\text {cat }}-\left(\mathbf{O H}_{2}{ }^{13}\right.$ or $\left.\mathbf{C l}^{12}\right)$ subunits, respectively (Figures $\mathrm{S} 6-\mathrm{S} 8$, Supporting Information). For all complexes a cathodic wave attributed to the one electron reversible reduction of the bpym ligand was observed. ${ }^{12}$ As a consequence of the Lewis acidity of the ruthenium cation, coordination of a second subunit to the bpym ligand resulted in a shift of this wave to a more positive potential (from -0.66 to -0.42 $\mathrm{V}$ vs NHE).

The cyclic voltammograms (CV) of $\mathbf{R} \mathbf{u}_{\text {phot }}-\mathbf{R} \mathbf{u}_{\text {cat }}-\mathbf{C l}$ and $\mathbf{R} \mathbf{u}_{\text {phot }}-$ $\mathbf{R} \mathbf{u}_{\text {cat }}-\mathbf{O H}_{2}$ showed, in addition to reduction of the bridging bpym ligand, two irreversible oxidation processes at +1.29 and $+0.92 \mathrm{~V}$ vs NHE, respectively (Figure 1). These waves were attributed to oxidation of the $\mathrm{Ru}_{\mathrm{cat}}$ center by comparison with the oxidation of $\left[\mathrm{Ru}(\text { diimine })_{3}\right]^{2+}$ systems which usually arise at higher potentials (in the range 1.4-1.9 $\mathrm{V}$ vs NHE, i.e., +1.51 and $+1.46 \mathrm{~V}$ vs NHE for the $\mathbf{R u}_{\text {phot }}$ and $\mathbf{R} \mathbf{u}_{\text {phot }}-\mathbf{R} \mathbf{u}_{\text {cat }}-\mathbf{O H}_{2}$ complexes, respectively). ${ }^{2 \mathrm{~b}}$ Only for $\mathbf{R} \mathbf{u}_{\text {phot }}-\mathbf{R} \mathbf{u}_{\text {cat }}-\mathbf{O H}_{2}$ the reversibility of the oxidation wave of the catalytic center can be observed at $200 \mathrm{mV} . \mathrm{s}^{-1}$ (Figures S9 and S10, Supporting Information). In the CV of the $\mathbf{R} \mathbf{u}_{\text {phot }}-\mathbf{R} \mathbf{u}_{\text {cat }}-\mathbf{C l}$ complex a small wave at $+0.92 \mathrm{~V}$ vs NHE becoming largely predominant after 2 days was assigned to the aquo species (Figure S11, Supporting Information). It is noteworthy that in such conditions, avoiding light exposure and $\mathrm{Co}(\mathrm{III})$ salt, the $\mathrm{Cl}^{-} / \mathrm{H}_{2} \mathrm{O}$ ligand exchange proved to be largely slower than in the photocatalytic conditions used for sulfide oxygenation.

An experiment using a rotating disk electrode (RDE, $500 \mathrm{rpm}$, inset Figure 1) showed unambiguously that oxidation of the $\mathrm{Ru}_{\mathrm{cat}}(\mathrm{II})-\mathrm{OH}_{2}$ subunit is a two electron process yielding a $\mathrm{Ru}_{\text {cat }}(\mathrm{IV})=\mathrm{O}$ species. This was confirmed by analysis of its relative current intensity (integrated area) compared to the one of the bpym reduction, which is a one electron process. Moreover, it was also observed that this oxidation potential decreased linearly with $\mathrm{pH}$ over the range $\mathrm{pH} \mathrm{1-7}$ with a slope of $-0.056 \mathrm{~V} / \mathrm{pH}$ unit (Figure S12, Supporting Information). These data are in agreement with a PCET process involving two protons and two electrons avoiding charge build up during oxidation. As a consequence, the oxidation potential of the $\mathrm{Ru}_{\text {cat }}(\mathrm{IV})=\mathrm{O} /$ $\mathrm{Ru}_{\text {cat }}(\mathrm{II})-\mathrm{OH}_{2}$ couple is lower than that corresponding to the $\mathrm{Ru}_{\text {cat }}(\mathrm{III})-\mathrm{Cl} / \mathrm{Ru}_{\text {cat }}$ (II) $-\mathrm{Cl}$ couple for which no PCET process is involved, even though the $\mathrm{Cl}^{-}$ligand is negatively charged and a strong donor. ${ }^{19}$ Finally, as the potential of the $\mathrm{Ru}_{\text {phot }}$ (III) $/ \mathrm{Ru}_{\text {phot }}$ (II) couple is higher than the one of the $\mathrm{Ru}_{\mathrm{cat}}$ (IV)/ $\mathrm{Ru}_{\text {cat }}$ (II) couple in the $\mathrm{Ru}_{\text {phot }}-$ $\mathbf{R u}_{\text {cat }}-\mathbf{O H}_{2}$ complex oxidation of the $\mathrm{Ru}_{\text {cat }}$ (II) $-\mathrm{OH}_{2}$ fragment into a versatile oxidant $\mathrm{Ru}_{\text {cat }}(\mathrm{IV})=\mathrm{O}$ species by the photogenerated $\mathrm{Ru}_{\text {phot }}$ (III) is favored.

Oxygen Atom Transfer from $\mathrm{H}_{2} \mathrm{O}$ to the Substrate. In order to highlight the oxygen atom transfer from the water molecule to the substrate, an isotopic labeling study employing a 1:1 mixture of $\mathrm{H}_{2}{ }^{18} \mathrm{O}$ and $\mathrm{H}_{2}{ }^{16} \mathrm{O}$ was carried out. After the usual extractions the product mixture was analyzed by GC MS, and the results were compared to the unlabeled sulfoxide displaying fragments at $\mathrm{m} / z 218$ and 220 (Figure 2). The mass spectra of the mixture disclosed formation of a 1:1 mixture of both labeled and unlabeled sulfoxide with fragments at $m / z 220,222$ and 218, 220 respectively. This result is fully consistent with an oxygen atom transfer from water to the substrate.

Photophysical Studies. To gain better insight into the photo physical behavior of the nonemissive dinuclear catalyst transient absorption spectroscopy was employed, exciting into different MLCT bands in the visible region under pseudocatalytic conditions in the absence of $\mathrm{Co}(\mathrm{III})$ salt. The excited behavior of model $\left[\left\{(\text { bpy })_{2} \mathbf{R u}\right\}_{2}(\text { bpym })\right]^{4+20}$ (named $\mathbf{R} \mathbf{u}_{\text {phot }}-\mathbf{R} \mathbf{u}_{\text {phot }}$ ) and $\mathbf{R} \mathbf{u}_{\text {phot }}-$ $\mathbf{R u} \mathbf{u}_{\text {cat }}-\mathbf{O H}_{2}$ was seen to be rather different (Figures 3 and 4). Exciting $\mathbf{R} \mathbf{u}_{\text {phot }}-\mathbf{R} \mathbf{u}_{\text {phot }}$ gave rise to a transient absorption signature attributed to a low lying MLCT state involving the easily reduced bridging ligand and an adjacent ruthenium with a lifetime of $1.8 \mathrm{~ns}$ in air equilibrated buffer solution. On the other hand, on exciting the dinuclear aquo complex a similar absorption signature is formed showing a similar intermediate based on the $\mathrm{Ru}_{\text {phot }}$ subunit, regardless of excitation wavelength. The lifetime is only $80 \mathrm{ps}$ (and insensitive to the presence of oxygen). The induced quenching may be attributed to an intramolecular photoinduced electron transfer (PET) reaction as suggested by the catalytic results. However, other quenching mechanisms cannot be entirely ruled out. Assuming the dominant quenching pathway is a PET process from $\mathrm{Ru}_{\text {cat }}$ to the excited state of the $\mathrm{Ru}_{\mathrm{phot}}$ subunit, a rate constant of $1.2 \times 10^{10} \mathrm{~s}^{-1}$ can be estimated, with a small net driving force of ca. $-0.1 \mathrm{eV}^{21}$ In spite of the short lived excited state under degassed conditions in the presence of 1000 equiv of cobalt salt this excited state lifetime was further shortened to around $55 \mathrm{ps}$, showing rapid diffusion, approaching the diffusion limit and/or static quenching, permitting electron transfer to the electron acceptor, potentially an important enabler in the catalytic reaction.

\section{DISCUSSION}

To date, it is well known that $\left[(\text { diimine }) \mathrm{Ru}(\mathrm{tpy})-\mathrm{OH}_{2}\right]^{2+}$ systems have an extensive and well defined catalytic oxidation chemistry involving the high valent $[(\text { diimine }) \mathrm{Ru}(\mathrm{tpy})=\mathrm{O}]^{2+}$ species. ${ }^{61}$ This system was shown to be particularly efficient for 
a)<smiles>CS(=O)c1ccc(Br)cc1</smiles>

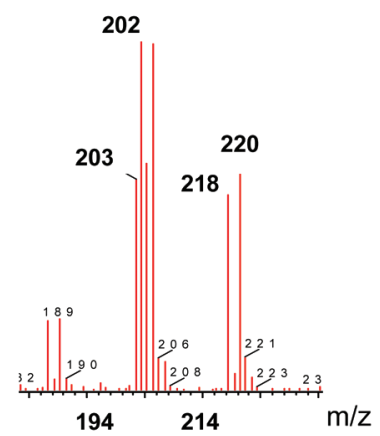

b)<smiles>CS(=O)c1ccc(N=[Te])cc1</smiles>

$1: 1$ ratio

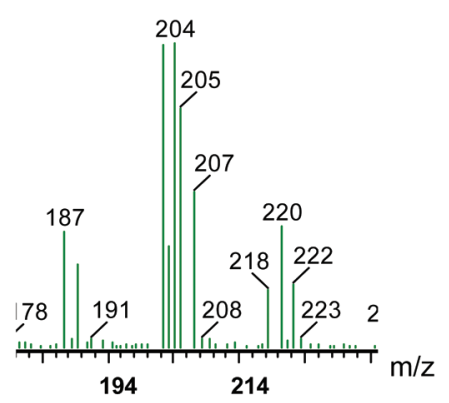

c)
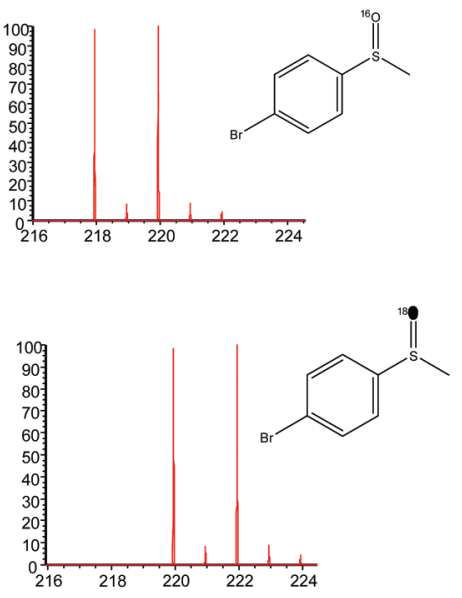

Figure 2. Experimental mass spectra of (a) the corresponding sulfoxide obtained using a standard procedure, (b) the corresponding labeled and unlabeled sulfoxides obtained in an unbuffered deoxygenated $\mathrm{H}_{2}{ }^{16} \mathrm{O}-\mathrm{H}_{2}{ }^{18} \mathrm{O} 1: 1$ mixture (instead of the buffered solution), and (c) simulated spectra of unlabeled 4 bromophenyl methyl sulfoxide (top) and ${ }^{18} \mathrm{O}$ labeled 4 bromophenyl methyl sulfoxide (bottom).
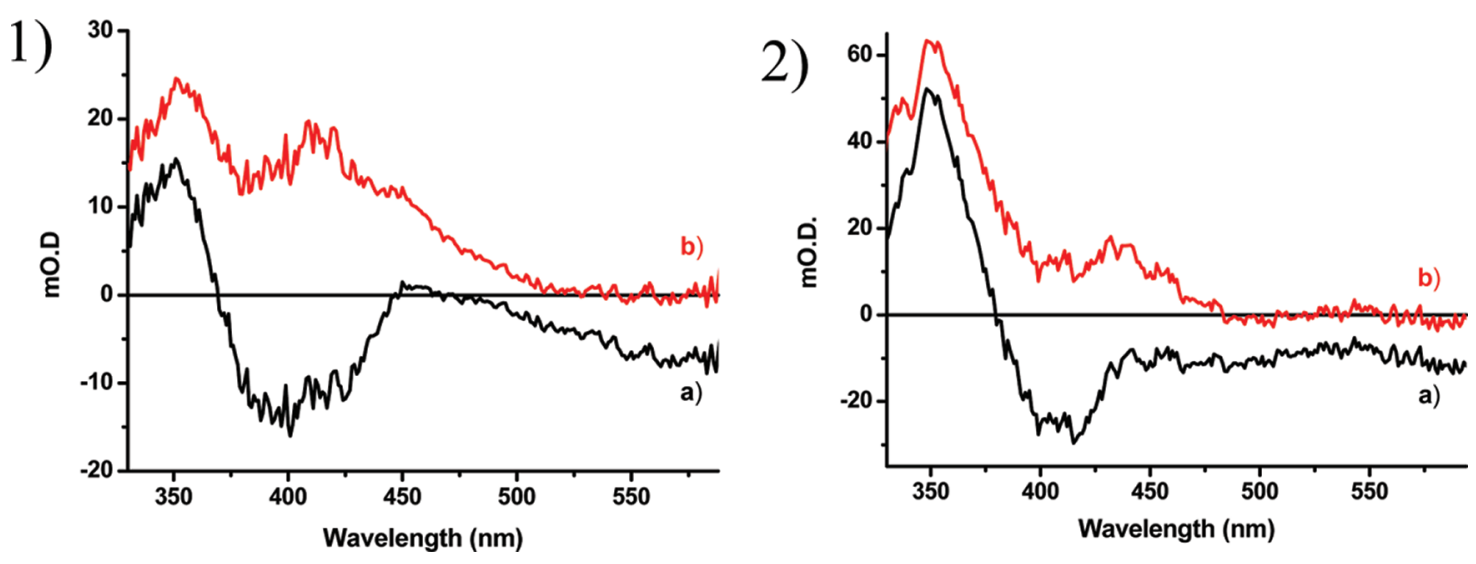

Figure 3. (1) (a) Transient absorption spectrum of $\mathbf{R} \mathbf{u}_{\text {phot }}-\mathbf{R} \mathbf{u}_{\text {phot }}$ and (b) calculated excited state absorption of $\mathbf{R} \mathbf{u}_{\text {phot }}-\mathbf{R} \mathbf{u}_{\text {phot }} \cdot \lambda_{\text {exc }}=430 \mathrm{~nm}$ in aqueous buffer solution. (2) (a) Transient absorption spectrum of $\mathbf{R} \mathbf{u}_{\text {phot }}-\mathbf{R} \mathbf{u}_{\text {cat }}-\mathbf{O H}_{2}$, and (b) calculated excited state absorption of $\mathbf{R} \mathbf{u}_{\mathrm{phot}}-\mathbf{R} \mathbf{u}_{\text {cat }}-$ $\mathrm{OH}_{2} \cdot \lambda_{\text {exc }}=430 \mathrm{~nm}$ in aqueous buffer solution.
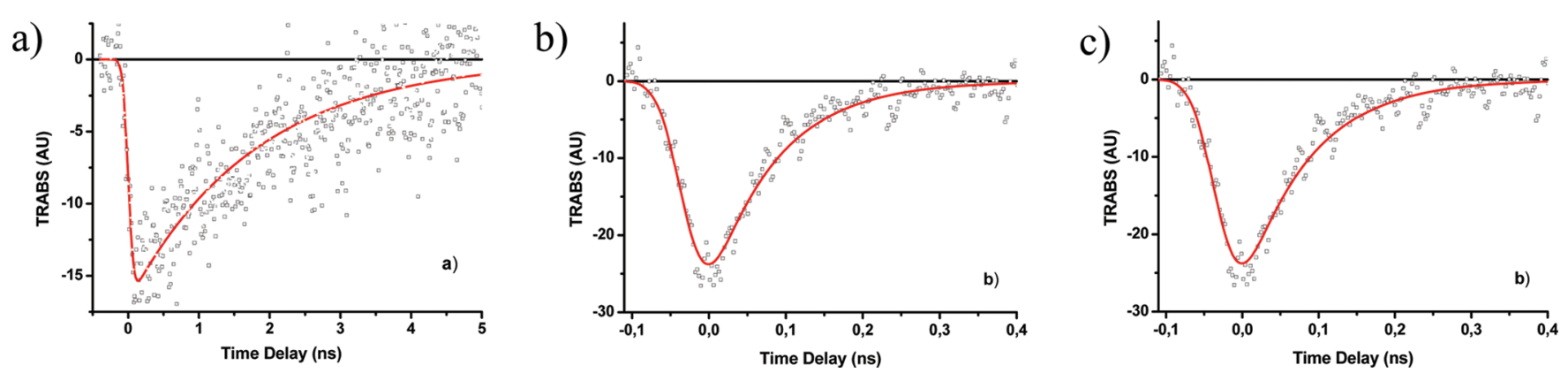

Figure 4. Kinetics model of transient absorption spectral changes at $430 \mathrm{~nm}$ : (a) $\mathbf{R} \mathbf{u}_{\text {phot }}-\mathbf{R} \mathbf{u}_{\text {phot }}(\tau=1.8 \mathrm{~ns})$, (b) $\mathbf{R} \mathbf{u}_{\text {phot }}-\mathbf{R u}_{\text {cat }}-\mathbf{O H}_{\mathbf{2}}(\tau=86 \mathrm{ps})$, and (c) $\mathbf{R} \mathbf{u}_{\text {phot }}-\mathbf{R u}_{\text {cat }}-\mathbf{O H}_{2}$ in the presence of electron acceptor (Co(III) salt 1000 equiv; $\tau=57 \mathrm{ps}$ ). $\lambda_{\text {exc }}=600$ nm in aqueous buffer solution.

catalytic oxidation of alcohols, aldehydes, and unsaturated hydrocarbons. $^{22}$ Through the pioneering work of T. J. Meyer it was also shown that the molecular assembly of a [(diimine) $\mathrm{Ru}(\mathrm{tpy})-\mathrm{OH}_{2}$ ] based catalyst with a chromophore allowed photodehydrogenation of propanol on $\mathrm{TiO}_{2} \cdot{ }^{23}$ With the system described here, by combining a photosensitizer and a $\left[(\right.$ bpy $) \mathrm{Ru}($ tpy $\left.)-\mathrm{OH}_{2}\right]$ like fragment we showed that the sulfoxide can be selectively and catalytically obtained without further overoxidation into the corresponding sulfone with a TON in the range of the ruthenium based bimolecular and binuclear photocatalysts reported by Rocha ${ }^{7}$ and very recently by $\operatorname{Sun}^{8 \mathrm{~b}}$ and our group. ${ }^{8 \mathrm{a}}$

The system reported here shows similar behavior with the $\left[(\text { bpy })_{2} \mathrm{Ru}(\text { tpphen }) \mathrm{Ru}(\text { bpy })\left(\mathrm{OH}_{2}\right)\right]^{4+}$ system reported very 
Scheme 3.

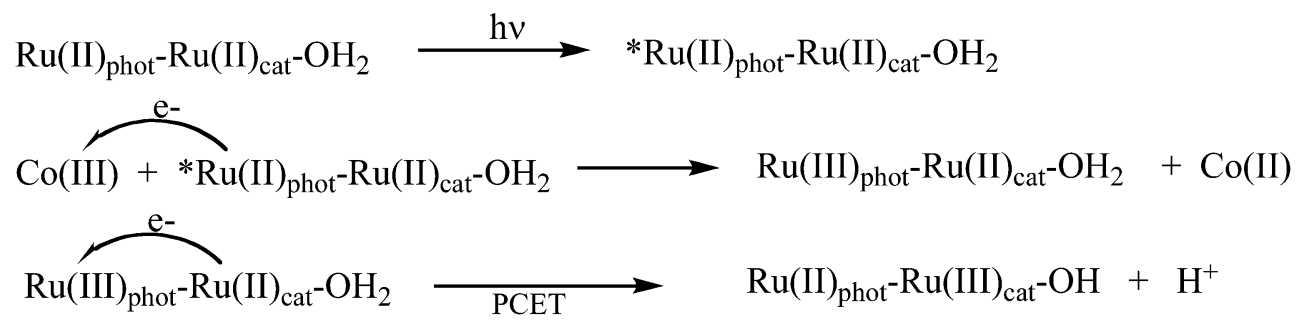

Disproportionation

$2 \mathrm{Ru}(\mathrm{II})_{\text {phot }}-\mathrm{Ru}(\mathrm{III})_{\text {cat }}-\mathrm{OH} \longrightarrow \mathrm{Ru}(\mathrm{II})_{\text {phot }}-\mathrm{Ru}(\mathrm{IV})_{\text {cat }}=\mathrm{O}+\mathrm{Ru}(\mathrm{II})_{\text {phot }}-\mathrm{Ru}(\mathrm{II})_{\mathrm{cat}}-\mathrm{OH}_{2}$

Step by step oxidation

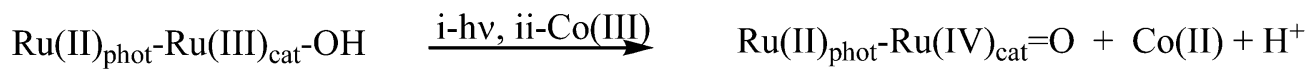

$\mathrm{Ru}(\mathrm{II})_{\text {phot }} \mathrm{Ru}(\mathrm{IV})_{\mathrm{cat}}=\oint+\mathrm{R}-\mathrm{S}-\mathrm{R}^{\prime}+\mathrm{H}_{2} \mathrm{O} \longrightarrow \mathrm{Ru}(\mathrm{II})_{\text {phot }}-\mathrm{Ru}(\mathrm{II})_{\mathrm{cat}}-\mathrm{OH}_{2}+\mathrm{R}-\mathrm{S}(\mathrm{O})-\mathrm{R}^{\prime}$

recently by us in terms of both the stability and the catalytic efficiency during sulfide oxygenation in the same conditions. This can be attributed to the relative structural homology between both dyads. More importantly, the results collected in Table 2 highlight the absolute necessity to associate both partners (chromophore and catalytic fragment) to be able to perform the photocatalytic reaction. Indeed, no product could be detected when they are used independently, whereas up to $56 \pm 4$ TON was reached by the bimolecular system. The dyad proved to be even more efficient with up to $131 \pm 6 \mathrm{TON}$ emphasizing the advantage of combining both partners within a unique photocatalytic entity for a better communication between them. This suggests that the (inter vs intra)molecular electron transfer from the catalyst to the photosensitizer directly impacts the efficiency of the photocatalytic system.

As far as the $\mathbf{R} \mathbf{u}_{\text {phot }}-\mathbf{R} \mathbf{u}_{\text {cat }}-\mathbf{C l}$ precursor is concerned, it was observed that several days are needed for its conversion into its corresponding aquo compound in water in the absence of silver salt (Figure S11, Supporting Information) while a few hours are required for the cation $[\mathrm{Ru}(\mathrm{tpy})(\mathrm{bpy}) \mathrm{Cl}]^{+} \cdot{ }^{19 a, 24}$ This difference in behavior can be attributed to the significant electron attracting effect of the $\mathrm{Ru}_{\text {phot }}$ moiety as it was noted by the group of C. P. Berlinguette that observed the rate of halide substitution by a water molecule is slower when bpy ligands bearing electron withdrawing substituents were used. ${ }^{19 a}$ How ever, when the $\mathbf{R} \mathbf{u}_{\text {phot }}-\mathbf{R} \mathbf{u}_{\text {cat }}-\mathbf{C l}$ complex was used for sulfide oxidation, an activity comparable to the aquo complex is observed after $24 \mathrm{~h}$. This could be ascribed to the rate acceleration of the $\mathrm{Cl}^{-} / \mathrm{H}_{2} \mathrm{O}$ exchange in the photocatalytic conditions affording the aquo photocatalyst from the $\mathrm{Ru}_{\mathrm{phot}}-$ $\mathbf{R} \mathbf{u}_{\text {cat }}-\mathbf{C l}$ precatalyst. However, it was observed that light is not the only parameter allowing this rate enhancement. Indeed, the $\mathbf{R} \mathbf{u}_{\text {phot }}-\mathbf{R} \mathbf{u}_{\text {cat }}-\mathbf{C l}$ system showed high stability (i) after several hours of light irradiation without the presence of the electron acceptor and also (ii) in water in the presence of the sulfide under dark conditions (data not shown). This suggests that all these parameters (light, $\mathrm{Co}$ (III), and maybe substrate also) have to be combined to allow this substitution in the experimental time window, leading to formation of the aquo catalyst.

In the four photocatalytic systems based on use of the [(diimine $) \mathrm{Ru}($ tpy $\left.)-\mathrm{OH}_{2}\right]$ like compound as catalyst in associ ation with a photosensitizer ${ }^{7,8 a, b, 23}$ a mechanism involving the two electron oxidation of the catalytic center thanks to a PCET process initiated by photon absorption by the chromophore fragment can be proposed (Scheme 3.). A similar mechanism occurs with the dyad system reported here. Excitation of the $\mathrm{Ru}_{\text {phot }}$ moiety by irradiation in the visible region corresponding to its MLCT absorption initiates an intramolecular electron transfer from the $\mathrm{Ru}_{\text {cat }}$ moiety to $\mathrm{Ru}_{\text {phot }}$ in its excited state, yielding formation of the $\left[\mathrm{Ru}_{\mathrm{phot}}(\mathrm{I})-\mathrm{Ru}_{\mathrm{cat}}(\mathrm{III})-\mathrm{OH}\right.$ (or $\left.\left.\mathrm{OH}_{2}\right)\right]^{3+(\text { or } 4+)}$ species as it was underlined by the photophysical studies in the absence of $\mathrm{Co}$ (III) salt. However, addition of a large excess of electron acceptor resulted in a small but significant diminution of the excited state lifetime (from 80 to $55 \mathrm{ps}$ ). Thus, an oxidative quenching involving intervention of a fast intermolecular electron transfer from $\mathrm{Ru}_{\text {phot }}$ in its excited state to the sacrificial electron acceptor generating the $\left.\left[\mathrm{Ru}_{\text {phot }}(\mathrm{III})-\mathrm{Ru}_{\mathrm{cat}}(\mathrm{II})-\mathrm{OH}_{2}\right)\right]^{4+}$ species may be proposed. This mechanism is generally accepted. ${ }^{8 \mathrm{a}, \mathrm{c}}$ Thanks to the higher $\mathrm{Ru}_{\text {phot }}$ potential relative to the $\mathrm{Ru}_{\mathrm{cat}}-\mathrm{OH}_{2}$ potential observed by cyclic voltammetry, the resulting $\mathrm{Ru}_{\text {phot }}$ (III) fragment is thermodynamically able to oxidize the neighboring $\mathrm{Ru}_{\text {cat }}$ (II)$\mathrm{OH}_{2}$ subunit by an intramolecular electron transfer. A proton is also released from the aquo ligand to avoid unfavorable charge build up during the oxidation process. In light of the reported mechanism for the $\left[\mathrm{Ru}(\mathrm{tpy})(\mathrm{bpym})-\mathrm{OH}_{2}\right]^{2+}$ catalyst $\left(\mathbf{R u}_{\mathrm{cat}}-\right.$ $\left.\mathrm{OH}_{2}\right)^{13,19 a, 24}$ and on the basis of the two electron oxidation observed for the $\mathrm{Ru}(\mathrm{II})_{\text {cat }}$ moiety (Figure 1) a mechanism involving disproportionation of $2\left[\mathbf{R} \mathbf{u}_{\mathrm{phot}}(\mathrm{II})-\mathbf{R} \mathbf{u}_{\mathrm{cat}}(\mathrm{III})-\right.$ $\mathbf{O H}]^{4+}$ into $\left[\mathbf{R u}_{\mathrm{phot}}(\mathrm{II})-\mathbf{R} \mathbf{u}_{\text {cat }}(\mathrm{IV})=\mathbf{O}\right]^{{ }^{++}}$and $\left[\mathbf{R u}_{\text {phot }}(\mathrm{II})-\right.$ $\mathbf{R} \mathbf{u}_{\text {cat }}($ II $\left.)-\mathrm{OH}_{2}\right]^{4+}$ may be proposed. However, a step by step oxidation of the $\left[\mathbf{R u}_{\text {phot }}(\mathrm{II})-\mathbf{R} \mathbf{u}_{\text {cat }}(\mathrm{II})-\mathbf{O H}_{2}\right]^{4+}$ complex into $\left[\mathbf{R} \mathbf{u}_{\text {phot }}(\mathbf{I I})-\mathbf{R} \mathbf{u}_{\text {cat }}(\mathbf{I V})=\mathbf{O}\right]^{4+}$ by two consecutive PCET processes cannot be entirely ruled out (Scheme 3.). This mechanism was proposed by T. J. Meyer for oxidation of water by $\mathrm{Ce}(\mathrm{IV})$ with the same dyad on the basis of electrochemical 
studies. ${ }^{10}$ Surprisingly, the $\mathrm{CV}$ of the $\mathbf{R} \mathbf{u}_{\text {phot }}-\mathbf{R} \mathbf{u}_{\text {cat }}-\mathbf{O H}_{\mathbf{2}}$ complex recorded in our laboratory in the same conditions (at $\mathrm{pH} 4.4$; acetate buffer) showed significant differences with the one published (Figure S13, Supporting Information). ${ }^{10}$ While two waves were observed at +0.75 and $+1.2 \mathrm{~V}$ vs NHE and attributed to successive one electron oxidation processes $\mathrm{Ru}(\mathrm{II})-\mathrm{OH}_{2} \rightarrow \mathrm{Ru}(\mathrm{III})-\mathrm{OH} \rightarrow \mathrm{Ru}(\mathrm{IV})=\mathrm{O}$, a single wave at $+1.05 \mathrm{~V}$ vs NHE corresponding to a two electron oxidation process was observed in our case. Our data $(\mathrm{CV}, \mathrm{RDE}$, and $\mathrm{E}$ $\mathrm{pH}$ experiments) strongly support a two electron two proton process, unambiguously attributed to oxidation of the $\mathrm{Ru}_{\text {cat }}$ (II) $-\mathrm{OH}_{2}$ fragment into a $\mathrm{Ru}_{\mathrm{cat}}(\mathrm{IV})=\mathrm{O}$ fragment, as also observed for the $\left[\mathrm{Ru}(\mathrm{tpy})(\mathrm{bpym}) \mathrm{OH}_{2}\right]^{2+}\left(\mathrm{Ru}_{\text {cat }}-\right.$ $\left.\mathbf{O H}_{2}\right),{ }^{13,19 a, 24}\left[(\text { bpy }) \mathrm{Ru}\left({ }^{i} \text { PrPybox }\right) \mathrm{OH}_{2}\right]^{2+25}$ and trans $[\mathrm{Ru}(\mathrm{II})$ pyrpy O)(tpy) $\left.-\mathrm{OH}_{2}\right]^{+26}$ complexes ( ${ }^{i}$ PrPybox $=2,6$ bis $[4$ isopropyl 2 oxazolin 2 yl]pyridine; pyrpy $=3,5$ dimethyl $2(2$ pyridyl)pyrrolate).

Then, similar to the proposed mechanism for water oxidation, the $\mathrm{Ru}(\mathrm{IV})=\mathrm{O}$ species undergoes nucleophilic attack of the sulfide to give the corresponding sulfoxide as a product with regeneration of the ruthenium aquo catalyst. Such a mechanism was also proposed during dimethylsulfide oxidation by $\left[(\text { bpy })_{2} \mathrm{Ru}(\mathrm{py})=\mathrm{O}\right]^{2+} .^{27}$ This mechanism was also suggested by the effect of the substituents on the phenyl ring of the sulfide with regard to the reactivity (Table 3) even though each substrate has a different solubility in the aqueous environment. However, as expected, the more electron donating the aryl substituent the more efficient the reaction.

In conclusion, we report herein the synthesis of a ruthenium based photocatalyst for sulfide photooxygenation. Similar to the first dyad system reported recently by our group, ${ }^{8 a}$ it was shown that combination of a light absorbing photosensitizing fragment and a catalytic subunit within the same entity affords a better catalytic activity compared to the bimolecular system. This emphasizes a more efficient synergistic effect between both partners in the dyad. This finding should represent an important consideration in the design of future catalysts for various oxygenation reactions.

\section{AUTHOR INFORMATION}

\section{Corresponding Author}

*E mail: olivier.hamelin@cea.fr.

\section{ACKNOWLEDGMENTS}

Financial support from the CNRS, MENRT, Université Bordeaux I, Région Aquitaine is gratefully acknowledged.

\section{REFERENCES}

(1) (a) Teply, F. Collect. Czech, Chem. Commun. 2011, 76, 859. (b) Narayanam, J. M. R.; Stephenson, C. R. J. Chem. Soc. Rev. 2011, 40, 102. (c) Inagaki, A.; Akita, M. Coord. Chem. Rev. 2010, 254, 1220. (d) Ravelli, D.; Dondi, D.; Fagnoni, M.; Albini, A. Chem. Soc. Rev. 2009, 38, 1999. (e) Zeitler, K. Angew. Chem., Int. Ed. 2009, 48, 9785. (f) Rau, D.; Walther, D.; Vos, J. G. Dalton Trans. 2007, 915. (g) Fagnoni, M.; Dondi, D.; Ravelli, D.; Albini, A. Chem. Rev. 2007, 107, 2725. (h) Sun, L.; Hammarström, L.; Akermark, B.; Styring, S. Chem. Soc. Rev. 2001, 30, 36. (i) De Cola, L.; Belser, P. Coord. Chem. Rev. 1998, 177, 301 and references cited therein.
(2) (a) Campagna, S.; Puntoriero, F.; Nastasi, F.; Bergamini, G.; Balzani, V. Top. Curr. Chem. 2007, 280, 117. (b) Juris, A.; Balzani, V.; Barigelletti, F.; Campagna, S.; Belser, P.; von Zelewsky, A. Coord. Chem. Rev. 1988, 84, 85.

(3) (a) Canoyelo, H.; Deronzier, A. J. Chem. Soc., Perkin Trans. 2 1984, 1093. (b) Canoyelo, H.; Deronzier, A. Tetrahedron Lett. 1984, $25,5517$.

(4) (a) Tran, P. D.; Artero, V.; Fontecave, M. Energy Environ. Sci. 2010, 3, 727. (b) Tucker, J. W.; Narayanam, J. M. R.; Krabbe, S. W.; Stephenson, C. R. J. Org. Lett. 2010, 12, 368. (c) Condie, A. G.; Gonzalez Gomez, J. C.; Stephenson, C. R. J. J. Am. Chem. Soc. 2010, 132, 1464. (d) Yoon, T. P.; Ischay, M. A.; Du, J. Nat. Chem. 2010, 2, 527. (e) Du, J.; Yoon, T. P. J. Am. Chem. Soc. 2009, 131, 14604. (f) Narayanam, J. M. R.; Tucker, J. W.; Stephenson, C. R. J. J. Am. Chem. Soc. 2009, 131, 8756. (g) Ischay, M. A.; Anzovino, M. E.; Du, J.; Yoon, T. P. J. Am. Chem. Soc. 2008, 130, 12886. (h) Fihri, A.; Artero, V.; Razavet, M.; Baffert, C.; Leibl, W.; Fontecave, M. Angew. Chem., Int. Ed. 2008, 47, 564. (i) Nicewicz, D. A.; MacMillan, D. W. C. Science 2008, 322, 77. (j) Renaud, P.; Leong, P. Science 2008, 322, 55. (k) Vos, J. G.; Kelly, J. M. Dalton Trans. 2006, 4869. (l) Huynh, M. H. V.; Dattelbaum, D. M.; Meyer, T. J. Coord. Chem. Rev. 2005, 249, 457. (m) Pellegrin, Y.; Quaranta, A.; Dorlet, P.; Charlot, M. F.; Leibl, W.; Aukauloo, A. Chem.-Eur. J. 2005, 11, 3698. (n) Lafolet, F.; Chauvin, J. M. N; Deronzier, A.; Laguitton Pasquier, H.; Leprêtre, J. C.; Vial, J. C.; Brasme, B. Phys. Chem. Chem. Phys. 2003, 5, 2520 . For photocatalytic water oxidation, see ref 5 . For photocatalytic oxidation of organic substrates, see refs 7 and 8 .

(5) (a) Duan, L.; Xu, Y.; Gorlov, M.; Tong, L.; Andersson, S.; Sun., L. Chem.-Eur. J. 2010, 16, 4659. (b) Xu, Y.; Duan, L.; Tong, L.; Akermark, B.; Sun, L. Chem. Commun. 2010, 46, 6506. (c) Duan, L.; Xu, Y.; Zhang, P.; Wang, M.; Sun, L. Inorg. Chem. 2010, 49, 209. (d) Puntoriero, F.; La Ganga, G.; Sartorel, A.; Carraro, M.; Scorrano, G.; Bonchio, M.; Campagna, S. Chem. Commun. 2010, 46, 4725. (e) La Ganga, G.; Nastasi, F.; Campagna, S.; Puntoriero, F. Dalton Trans. 2009, 9997. (f) Geletii, Y.; Huang, Z.; Hou, Y.; Musaev, G.; Lian, T.; Hill, C. L. J. Am. Chem. Soc. 2009, 131, 7522. (g) Harriman, A.; Porter, G.; Walters, P. J. Chem. Soc., Faraday Trans. 2 1981, 77, 2373. (h) Rotzinger, F. P.; Munavalli, S.; Comte, P.; Hurst, J. K.; Gratzel, M.; Pern, F. J.; Frank, A. J. J. Am. Chem. Soc. 1987, 109, 6619.

(6) (a) Naota, H.; Takaya, H.; Murahashi, S. I. Chem. Rev. 1998, 98, 2599. (b) Goldstein, A. S.; Beer, R. H.; Drago, R. S. J. Am. Chem. Soc. 1994, 116, 2424. (c) Collin, J. P.; Sauvage, J. P. Inorg. Chem. 1986, 25, 135. (d) Che, C. M.; Li, C. K.; Tang, W. T.; Yu, W. Y. J. Chem. Soc., Dalton Trans. 1992, 3153. (e) Che, C. M.; Cheng, K. W.; Chan, MV. C. W.; Lau, T. C.; Mak, C. K. J. Org. Chem. 2000, 65, 7996. (f) Chavarot, M.; Ménage, C; Hamelin, O.; Charnay, F.; Pécaut, J.; Fontecave, M. Inorg. Chem. 2003, 42, 4810. (g) Goldstein, A. S.; Drago, R. S. J. Chem. Soc., Chem. Commun. 1991, 21. (h) Hamelin, O.; Ménage, S.; Charnay, F.; Chavarot, M.; Pierre, J. L.; Pécaut, J.; Fontecave, M. Inorg. Chem. 2008, 47, 6413. (i) Meyer, T. J.; Huynh, M. H. V. Inorg. Chem. 2003, 42, 8140 and references therein. (j) Benet Buchholz, J.; Comba, P.; Llobet, A.; Roeser, S.; Vadivelu, P.; Wadepohl, H.; Wiesner, S. Dalton Trans. 2009, 5910. (k) Benet Buchholz, J.; Comba, P.; Llobet, A.; Roeser, S.; Vadivelu, P.; Wadepohl, H.; Wiesner, S. Dalton Trans. 2010, 39, 3315. (1) Hirai, Y.; Kojima, T.; Mizutani, Y.; Shiota, Y.; Yoshizawa, K.; Fukuzumi, S. Angew. Chem., Int. Ed. 2008, 47, 5772. (m) Huynh, M. H. V.; Witham, L. M.; Lasker, J. M.; Wetzler, M.; Mort, B.; Jameson, D. L.; White, P. S.; Takeuchi, K. J. J. Am. Chem. Soc. 2003, 125, 308.

(7) (a) Chen, W.; Rein, F. N.; Scott, B. L.; Rocha, R. C. Chem.-Eur. J. 2011, 17, 5595. (b) Chen, W.; Rein, F. N.; Rocha, R. C. Angew. Chem., Int. Ed. 2009, 48, 9672.

(8) (a) Hamelin, O.; Guillo, P.; Loiseau, F.; Boissonnet, M. F.; Menage, S. Inorg. Chem. 2011, 50, 7952. A few bimolecular systems, most of them reported during this work, were also reported for photocatalytic sulfide and alkene oxygenation: (b) Li, F.; Yu, M.; Jiang, Y.; Huang, F.; Li, Y.; Zhang, B.; Sun, L. Chem. Commun. 2011, 47, 
8949. (c) Fukuzumi, S.; Kishi, T.; Kotani, H.; Lee, Y. M.; Nam, W. Nat. Chem. 2011, 38. (d) Kalita, D.; Radaram, B.; Brooks, B.; Kannam, P. P.; Zhao, X. Chem. Catal. Chem 2011, 3, 571. (e) Zen, J. M.; Liou, S. L.; Kumar, A. S.; Hsia, M. S. Angew. Chem., Int. Ed. 2003, 42, 577. see also (f) Bonesi, S. M.; Carbonell, E.; Garcia, H.; Fagnoni, M.; Albini, A. Appl. Catal. B 2008, 79, 368.

(9) (a) Hamelin, O.; Rimboud, M.; Pécaut, J.; Fontecave, M. Inorg. Chem. 2007, 46, 5354. (b) Ji, Z; Huang, S. D.; Gadalupe, A. R. Inorg. Chim. Acta 2000, 305, 127.

(10) (a) Conception, J. J.; Jurss, J. W.; Hoertz, P. G.; Meyer, T. J. Angew. Chem., Int. Ed. 2009, 48, 9473. (b) Conception, J. J; Jurss, J. W.; Brennaman, M. K.; Hoertz, P. G.; Patrocinio, A. O. T.; Iha, N. Y. M.; Templeton, J. L.; Meyer, T. J. Acc. Chem. Res. 2009, 42, 1954.

(11) Yang, J.; Seneviratne, D.; Arbatin, G.; Andersson, A. M.; Curtis, J. C. J. Am. Chem. Soc. 1997, 119, 5329.

(12) Swavey, S.; Fang, Z.; Brewer, K. J. Inorg. Chem. 2002, 41, 2598.

(13) Conception, J. J.; Jurss, J. W.; Templeton, J. L.; Meyer, T. J. J. Am. Chem. Soc. 2008, 130, 16462.

(14) Cabaniss, G. E.; Diamantis, A. A.; Murphy, W. R. Jr.; Linton, R. W.; Meyer, T. J. J. Am. Chem. Soc. 1985, 107, 1845.

(15) (a) Montalti, M.; Credi, A.; Prodi, L.; Gandoffi, M. Handbook of photochemistry, 3rd ed.; Taylor \& Francis Group and CRC Press: Boca Raton, FL, 2006. (b) Kuhn, H. J.; Braslavsky, S. E.; Schmidt, R. Pure Appl. Chem. 2004, 12, 2105.

(16) Jakubikova, E.; Chen, W.; Dattelbaum, D. M.; Rein, F. N.; Rocha, R. C.; Martin, R. L.; Batista, E. R. Inorg. Chem. 2009, 48, 10720.

(17) (a) Fernandez, I.; Khiar, N. Chem. Rev. 2003, 103, 3651. (b) Carreno, M. C. Chem. Rev. 1995, 95, 1717.

(18) (a) Baciocchi, E.; Del Giacco, T.; Ferrero, M. I.; Rol, C.; Sebastiani, G. V. J. Org. Chem. 1997, 62, 4015. (b) Clennan, E. L.; Aebisher, D. J. Org. Chem. 2002, 67, 1036. (c) Panayotov, D. A.; Paul, D. K.; Yates, J. T. J. Phys. Chem. B 2003, 107, 10571. (d) Fujita, S.; Sato, H.; Kakegawa, N.; Yamagishi, A. J. Phys. Chem. B 2006, 110, 2533.

(19) (a) Wasylenko, D. J.; Ganesamoorthy, C.; Koivisto, B. D.; Berlinguette, C. P. Eur. J. Inorg. Chem. 2010, 3135. (b) Takeuchi, K. J.; Thompson, M. S.; Pipes, D. W.; Meyer, T. J. Inorg. Chem. 1984, 23, 1845 . For the $\left[\mathrm{Ru}(\text { tpy })(\text { bpym })\left(\mathrm{OH}_{2}\right)\right]^{2+}$ complex, see refs $10 \mathrm{~b}$ and 13.

(20) Goldsby, K. A.; Meyer, T. J. Inorg. Chem. 1984, 23, 3002.

(21) Rehm, D.; Weller, A. Isr. J. Chem. 1970, 8, 259.

(22) (a) Thompson, M. S.; De Giovani, W. F.; Moyer, B. A.; Meyer, T. J. J. Org. Chem. 1984, 49, 4972. (b) Thompson, M. S.; Meyer, T. J. J. Am. Chem. Soc. 1982, 104, 5070. (c) Moyer, B. A.; Thompson, M. S.; Meyer, T. J. J. Am. Chem. Soc. 1980, 102, 2310. (d) Farrer, B. T.; Thorp, H. H. Inorg. Chem. 1999, 38, 2497. (e) Madurro, J. M.; Chiericato, G. Jr.; De Giovani, W. F.; Romero, J. S. Tetrahedron Lett. 1988, 29, 765.

(23) Treadway, J. A.; Moss, J. A.; Meyer, T. J. Inorg. Chem. 1999, 38, 4385.

(24) Concepcion, J. J.; Tsai, M. K.; Muckerman, J. T.; Meyer, T. J. J. Am. Chem. Soc. 2010, 132, 1545.

(25) Hua, X.; Shang, M.; Lappin, A. G. Inorg. Chem. 1997, 36, 3735.

(26) Dakkach, M.; Lopez, M. I.; Romero, I.; Rodriguez, M.; Atlamsani, A.; Parella, T.; Fontrodona, X.; Llobet, A. Inorg. Chem. 2010, 49, 7072 .

(27) Roecker, L.; Dobson, J. C.; Vining, W. J.; Meyer, T. J. Inorg. Chem. 1987, 26, 779 . 